\title{
Relationship Between Internal Control, Internal Audit, and Organization Commitment With Good Governance: Indonesian Case
}

\author{
Eko Suyono, Eko Hariyanto \\ University of Jenderal Soedirman, Purwokerto, Indonesia
}

\begin{abstract}
The aims of this research are to examine the relationship between internal control, internal audit, and organization commitment with the good governance. Internal control consists of the organization planning that includes all methods used to safeguard the company assets, to insure the reliability of information, to support the efficiency and effectiveness of operations, and to insure the compliance with rules and regulations. Internal audit is an organization which functions with the duties to assess and evaluate all activities within the organization. Organization commitment is defined as the individual relative power to identify his/her self into the organization. Governance has been variously defined as the exercise of authority or control to manage a country's affairs and resources. The type of data in this research is primary data that could be collected by questionnaires which were distributed to the respondents. The populations of this research are local government of Central Java province, Indonesia which consists of 35 regions. The respondents include head of local government inspectorate, head of monitoring division in local government inspectorate, head of internal audit team, and head of region. Therefore, 35 sets of questionnaires were distributed to respondents from February to July in 2011. Exogenous variables are the internal control, audit internal, and organization commitment. Meanwhile, endogenous variables are good governance. With multiple linier regression analysis, the finding showed that internal control, internal audit, and organization commitment have positive significant relationship with the good governance. It means that when local government of Central Java province implements the internal control effectively, audit internal and high organization commitment, therefore makes the good governance practices increase.
\end{abstract}

Keywords: internal control, internal audit, organization commitment, good governance

\section{Introduction}

The survey by Transparency International (2009) reported that the corruption rank of Indonesia is at the number of 111 from 180 nations with the score of 2.8. The low score of good governance implementation and the high range of corruptions mean that there is no accountability in the government financial management (Mardiasmo, 2004). Good governance and internal control became a highly pertinent and topical business issue at the beginning of the 21 st century, following a series of large corporate scandals and failures (PABC, 2006).

Eko Suyono, Dr., MSi, Ak, Faculty of Economics and Business, University of Jenderal Soedirman.

Eko Hariyanto, Dr., MSi, Ak, Faculty of Economics and Business, University of Jenderal Soedirman.

Correspondence concerning this article should be addressed to Dr. Eko Suyono, MSi, Ak, Jl. HR. Boenyamin 708, Purwokerto, Central Java, Indonesia. E-mail: ekyo75@yahoo.com; hariyanto_eko1@yahoo.com. 
The government internal auditors consist of general inspectorate, provincial inspectorate, region or city inspectorate, and indonesian financial regulatory body and the developement (Mardiasmo, 2004). The head of local governments must have a high commitment to regulate, identify, and understand the financial reporting mechanism. They also must be responsible for preventing from the fraud in enforcing the public funds, by implementing the effective internal control (Ratliff, Wallace, Loebbecke, \& Farlan, 1996).

Cheung and Qiang (2002) found that the internal audit function in the organization improved the good corporate governance. Stewart and Kent (2006) who made a research at Australian also had a similar finding.

The success of good governance implementation also depends on the organization commitment by all heads and staffs of govermental agencies. Mowday, Stees, and Porter (1979) explained that organization commitment represented the stong bilieveness on the all organization values and goals.

Based on the explanation at above, problems in this research are as follows:

(1) Does the internal control have a positive relationship with the good corporate governance?

(2) Does the internal audit have a positive relationship with the good governance?

(3) Does the organization commitment have a positive relationship with the good governance?

\section{Theory and Hypothesis}

\section{Internal Control}

Internal control consists of the organization planning that includes all methods used to safeguard the company assets, to insure the reliability of information, to support the efficiency and effectiveness of operations, and to insure the compliance with rules and regulations (Arens, Elder, \& Beasley, 2010).

The regulation of Indonesia Government No. 60 (2008) in paragraph 1 of section 1 defines the government internal control system as follows:

an integrated process on activities and actions that enforced continuously by managers and all employees to give adequate assurance in achieving the organization goals by efficient and effective manner, by the reliability of financial report, by safeguarding government assets, and by compliance with rules and regulations. (p. 2)

Mensah, Aboagye, Addo, and Buatsi (2003) found empirical evidence in Ghana that effective internal control improved good governance practices and decreased the corruptions. Pratolo (2007) found that the effective internal control had positive link with good corporate governance at State Owned Enterprises in Indonesia. Similar with this finding, Nila and Viriyanti (2008) also found that internal control had a positive relationship with good corporate governance at State Owned Enterprises in West Java, Indonesia.

\section{Internal Audit}

Internal audit is an organization function with the duties to assess and evaluate all activities within the organization. This function is very important to provide and support all information in managerial decision-making process.

Similar with external audit, an internal audit also has to be independent in conducting his/her duties. Internal auditors' independence consists of two aspects, i.e., (1) the separation of this function with the auditee; and (2) the status within the organization.

Virginia et al (2009) found that internal audit had a role to prevent the corruptions and support the good governance practices. Yasin et al. (2011) found that the internal audit function had a significant role in supporting the good governance practices. This finding was also similar with Wallace and Kreutzfeldt (1991); 
Carey et al. (2000); Gramling et al. (2004) and Carcello et al. (2005); and Coram and Moroney (2007).

\section{Organization Commitment}

Organization commitment is defined as the individual relative power to identify his/her self into the organization (Mowday et al., 1979). It is chategorized in three dimensions (Allen \& Meyers, 1996), i.e., (1) affective, namely, denoting an emotional attachment to identification and involvement in the organization; (2) continuance, namely, denoting the perceived costs associated with leaving the organization; and (3) normative, namely, reflects a perceived obligation to remain in the organization.

Stanton et al. (2003) found an empirical evidence that individuals whose organizational commitment was high, they may spend more time on productive work activities. Brown (2003) found that relations-oriented leadership behaviors explained the greatest amount of variance in affective commitment, somewhat less variance in normative commitment, and no variance in continuance commitment. Other prior researchers have found relationships between organizational commitment and attitudes and behaviors in the workplace (Porter et al., 1974; Steers, 1977; and Angle \& Perry, 1981).

\section{Good Governance}

Governance has been variously defined as "the exercise of authority or control to manage a country's affairs and resources" (Schneider, 1999). Good governance requires that the government is governed in accordance with the governance principles, namely, transparency, accountability, reasponsibility, participation, fairness, and independency. The National Committee of Governance Polecy (2010) argued that the implementation of good governance principles would like to give strategies which contributed to: (1) increasing social welfare; (2) creating condusive business environment; (3) improving the bargaining power; and (4) preventing from all frauds in running the governmental duties.

Mensah et al. (2003) reported that corporate governance was one of the most effective tools to reduce the incidence of corruption, especially in the corporate sector. Kajola and Sunday (2008) found an empirical evidence in Nigeria that chief executive status as one proxy of corporate governance had positive significant relationship with firm performance that proxied with profit margin

Based on explanations above, the framework of thinking in this research is shown in the following Figure 1:

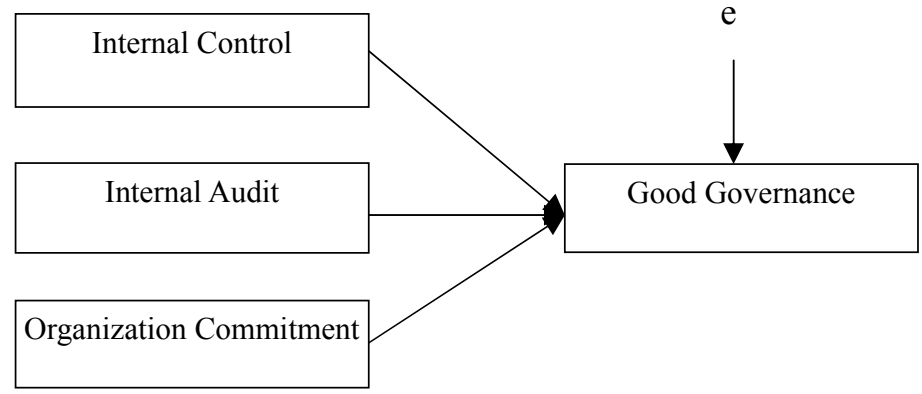

Figure 1. Framework of Thinking.

Base on explanations above, the hypotheses in this research are as follows:

H1: The internal control has a positive significant relationship with the good governance;

$\mathrm{H} 2$ : The internal audit has a positive significant relationship with the good governance;

H3: The organization commitment has a positive significant relationship with the good governance. 


\section{Methodology}

\section{Research Method}

This research uses a survey method, with the respondents in this research who are head of local government inspectorate, head of monitoring division in local government inspectorate, head of internal audit team, and head of region. There are 35 regions in Central Java province, Indonesia. Therefore, 35 sets of questionnaires were distributed to respondents from February to July in 2011.

\section{Variables and Measurement}

(1) Internal control $\left(\mathrm{X}_{1}\right)$, is measured by instrument developed by COSO (1999), namely, control environment, risk assessment, control activity, information and communication, and monitoring;

(2) Internal audit $\left(\mathrm{X}_{2}\right)$, is measured by instrument developed by Moeller (2005) in Sawyers et al. (2003), namely, independence, professional competency, scope of work, examination process, and audit internal management;

(3) Organization commitment $\left(\mathrm{X}_{3}\right)$, is measured by instrument developed by Meyer and Allen (1997), namely, affective, continuance, and normative.

(4) Good governance (Y), is measured by instrument developed by World Bank (2003), and Asian Development Bank (1999), namely, transparency, participation, accountability, independency, and responsibility.

\section{Analysis}

Validity Testing. The purpose of validity testing is to know how far the instruments measured correctly and accurately. Validity testing uses product moment correlation, with the criteria of acceptance as the following:

The item of questioner is valid if $r_{\text {statistic }}$ is higher than critical value at degree of freedom $95 \%(\alpha=0.05)$.

Reliability Testing. The purpose of reliability testing is to examine the consitency of the data. In this research, the reliability is measured by internal consistency approach, that is the concept stressing on the consistency between items in the questionnaires. A construct or variable is reliable if the Croanbach's Alpha is more than 0.6 (Ghazali, 2006).

After all instruments were tested, the clasical assumption of multiple linier regression was tested from the following aspects (Ghazali, 2006):

(1) Normality Testing. The purpose of normality testing is to know that all data of independent and dependent variables have normal distribution. In this research, normality testing is used based on colmogorov-smirnov, in which if the assymptotic significant (two tail) is higher than alpha $(\alpha=0.05$ ), so all data have normal distribution;

(2) Multicolinearity Testing. Multicolinearity is a condition in which one or more indepedent variables are in a linear contribution with other independent variables. Multicolinearity testing can be analyzed from variance inflation factor (VIF), in which if VIF is less than 10, there is no multicolinearity;

(3) Heteroskedasticity Testing. Heteroskedasticity is occurred when variance disturbance is not consistent to one to another time at all observations. Heteroskedasticity testing uses a park glejser method, in which if the probability value is higher than alpha $(\alpha=0.05)$, there is no heteroskedasticiy.

\section{Hypothesis Testing}

There is one dependent variable corelated to three independent variables. Therefore, this research will be 
analyzed based on multiple linier regression, with the following equation:

$$
\mathrm{Y}=\mathrm{a}+\mathrm{b}_{1} \mathrm{X}_{1}+\mathrm{b}_{2} \mathrm{X}_{2}+\mathrm{b}_{3} \mathrm{X}_{3}+e
$$

Explanation:

$\mathrm{Y}=$ good governance;

$\mathrm{a}=$ value of $\mathrm{Y}$ if $\mathrm{X}_{1}, \mathrm{X}_{2}, \mathrm{X}_{3}=0$;

$\mathrm{b}_{1}, \mathrm{~b}_{2}, \mathrm{~b}_{3}=$ coefficients of regression;

$\mathrm{X}_{1}=$ internal control;

$\mathrm{X}_{2}=$ internal audit;

$\mathrm{X}_{3}=$ organization commitment;

$e=$ residual value.

Before all hypotheses are tested, the goodness of fit of the model in this research is tested with F-test in the following formula (Gujarati, 2003; and Ghazali, 2006):

$$
\mathrm{F}=\frac{\mathrm{R}^{2} /(k-1)}{1-\mathrm{R}^{2} /(n-k)}
$$

Explanation :

$\mathrm{F}=\mathrm{F}$ value that is resulted from the calculation;

$\mathrm{R}^{2}=$ coefficient of determination;

$k=$ number of variables;

$n=$ number of observations.

The criteria of testing are as the following:

The model in this research does not have a goodness of fit, if $\mathrm{F}_{\text {statistic }}$ is smaller than critical value $\left(\mathrm{F}_{\text {table }}\right)$, and the model have goodness of fit if $\mathrm{F}_{\text {statistic }}$ is higher than critical value.

First Hypothesis Testing. First hypothesis is tested by $t$-test in the following formula (Ghazali, 2006):

Explanation:

$$
\mathrm{t}=\frac{\mathrm{b}_{\mathrm{j}}}{\mathrm{S}_{\mathrm{bj}}}
$$

$\mathrm{T}=t$ value that is resulted from the calculation;

$\mathrm{b}_{\mathrm{j}}=$ coefficient of regression;

$\mathrm{S}_{\mathrm{bj}}=$ standard error of regression coefficient.

The criteria of testing are as follows:

$\mathrm{H}_{0}: \mathrm{b}_{1} \leq 0$ (internal control does not have a positive significant relationship with good governance);

$\mathrm{H}_{0}: \mathrm{b}_{1}>0$ (internal control has a positive significant relationship with good governance).

Then, $\mathrm{H}_{0}$ would be accepted if $\mathrm{t}_{\text {ststistic }}$ is smaller than critical value, and $\mathrm{H}_{0}$ would be rejected if $\mathrm{t}_{\text {statistic }}$ is higher than critical value.

Second Hypothesis Testing. Second hypothesis is tested by $t$-test, in the following criteria of testing:

$\mathrm{H}_{0}: \mathrm{b}_{2} \leq 0$ (internal audit does not have a positive significant relationship with good governance);

$\mathrm{H}_{0}: \mathrm{b}_{2}>0$ (internal audit has a positive significant relationship with good governance).

Then, $\mathrm{H}_{0}$ would be accepted if $\mathrm{t}_{\text {ststistic }}$ is smaller than critical value, and $\mathrm{H}_{0}$ would be rejected if $\mathrm{t}_{\text {statistic }}$ is higher than critical value.

Third Hypothesis Testing. Third hypothesis is tested by $t$-test in the following criteria of testing: 
$\mathrm{H}_{0}: \mathrm{b}_{3} \leq 0$ (organization commitment does not have a positive significant relationship with good governance);

$\mathrm{H}_{0}: \mathrm{b}_{3}>0$ (organization commitment has a positive significant relationship with good governance).

Then, $\mathrm{H}_{0}$ would be accepted if $\mathrm{t}_{\text {ststistic }}$ is smaller than critical value, and $\mathrm{H}_{0}$ would be rejected if $\mathrm{t}_{\text {statistic }}$ is higher than critical value.

\section{Finding and Discussion}

\section{Finding of Validity and Reliability Testing}

The results of all corelation coefficient for questionnaire items have total scores of more than 0.3 (critical value), thus all data in this research are valid. While the result of reliability testing by using croanbach's alpha for internal control is 0.714 ; audit internal is 0.722 ; organization commitment is 0.759 ; and the good governance is 0.765 . It means that all values of croanbach's alpha are more than 0.6. Thus all data are reliable.

\section{Finding of Clasical Assumption Testing}

Normality. The result of Kolmogorof-Smirnove shows that the value of asymtotic significant is 0.695 which is higher than alpha $(\alpha=0.05)$. It means that all data have normal distribution.

Heteroskedasticity. Output of Park Glejser test shows that significance of internal control (0.950), audit internal (0.554), and organization commitment $(0.796)$, are higher than alpha $(\alpha=0.05)$. It means that there is no heteroskedasticity in this model.

Multicolinearity. Output of variance inflation factor (VIF) shows that VIF for internal control (2.173), internal audit (1.119), and organization commitment (2.279), are smaller than 10. It means that there is no multicolinearity between independent variables.

\section{Finding of Hypothesis Testing}

The output of multiple regression analysis is in the following Table 1:

Table1

Summary of F-test and t-test

\begin{tabular}{|c|c|c|c|c|c|c|c|}
\hline \multirow[b]{2}{*}{ Variables } & \multicolumn{6}{|c|}{$F$-test and $t$-test } & \multirow[b]{2}{*}{ Conclusion } \\
\hline & $\mathrm{F}_{\text {statistic }}$ & \begin{tabular}{|l} 
critical \\
value
\end{tabular} & \multirow{2}{*}{$\begin{array}{l}\text { regression } \\
\text { coefficient }\end{array}$} & $\mathrm{t}_{\text {statistic }}$ & \begin{tabular}{|l} 
critical \\
value
\end{tabular} & $P$-value & \\
\hline Goodness of fit testing & 7.486 & 2.87 & & & & 0.002 & Significant \\
\hline \multicolumn{8}{|l|}{ Partially testing } \\
\hline \multicolumn{3}{|l|}{ constant } & 0.021 & 5.143 & 1.72 & 0.009 & Significant \\
\hline \multicolumn{3}{|l|}{ Internal Control } & 0.201 & 3.875 & 1.72 & 0.005 & Significant \\
\hline \multicolumn{3}{|l|}{ Internal Audit } & 0.123 & 4.463 & 1.72 & 0.049 & Significant \\
\hline \multicolumn{3}{|c|}{ Organization Commitment } & 0.807 & 2.511 & 1.72 & 0.023 & Significant \\
\hline
\end{tabular}

Notes. Dependent variable: Good governance; Source: Output of statistical test with SPSS for $f$-test and $t$-test on the appendics 5 in the full version of the research report.

Based on Table 1, the regeression equation is as follows :

$$
\mathrm{Y}=0.021+0.201 \mathrm{X}_{1}+0.123 \mathrm{X}_{2}+0.807 \mathrm{X}_{3}+\varepsilon
$$

Before hypotheses are tested, we have to test the goodness of fit of the model in this research. From the result of $F$-test, it is known that the $\mathrm{F}_{\text {statistic }} 7.486$ is higher than the critical value (2.87) and the probaility 0.002 is smaller than alpha (0.05). Therefore, the model is fit. 
First Hypothesis Testing. The value of $\mathrm{t}_{\text {statistic }}$ for variable of internal control is 3.875 higher than critical value (1.72), and p-value of 0.005 is smaller than alpha (0.05). It means that internal control has a positive significant relationship with good governance.

Second Hypothesis Testing. The value of $\mathrm{t}_{\text {statistic }}$ for variable of internal audit is 4.462 higher than critical value (1.72), and p-value of 0.049 is smaller than alpha (0.05). It means that internal audit has a positive significant relationship with good governance.

Third Hypothesis Testing. The value of $t_{\text {statistic }}$ for variable of organization commitment 2.511 is higher than critical value (1.72), and p-value of 0.023 is smaller than alpha (0.05). It means that organization commitment has a positive relationship with good governance.

\section{Discussion}

The finding of this research, in which internal control has positive significant relationship with good governance, is in accordance with the results of Cheung and Qiang (2002); Mensah et al. (2003); Stewart and Kent (2006); Pratolo (2007); and Nila and Vitriyanti (2008). The rationalization of this finding is that the internal control can give assurance in the reliability of financial reporting, efficient and effective operation, and compliance with rules and regulations. Therefore, if the internal control within the organization runs well, the good governance practices can be automatically improved.

Consistent with the prior study, this research shows that variable of internal audit has a positive significant relationship with the good governance. This finding is in line with Virginia et al. (2009); Yasin et al. (2011); Wallace and Kreutzfeldt (1991); Carey et al. (2000); Gramling et al. (2004); Carcello et al. (2005); and Coram and Moroney (2007). The rationalization of this finding is that the internal audit function has important roles in governing the organization, such as controlling, evaluating, monitoring, and advising the head of local government. If the internal audit runs his/her roles effectively, the governance mechanism will run well and the good governance practices can be improved.

The finding of this research, in which organization commitment has positive significant relationship with good governance, provides new evidence to support the theoretical concept and future research. Because there was no research before that was related to the organization commitment and good government, particularly in public sector. The rationalization of this finding is that the organization commitment, especially from head of local government and all staffs give strong power in governing the organization.

\section{Conclusions}

Like other prior researches, this research found that internal control has a positive significant relationship with the good governance at Central Java Province, Indonesia. Similar finding also showed that internal audit has a positive significant relationship with good governance. Other finding showed that organization commitment has a positive significant relationship with the good governance. The finding gives new knowledge because there is not any research before which was related between organization commitment and good governance.

This research can contribute the arguments on similar ideas that may be used by anybody who is interested in this issue, particularly for the government agencies, so that they can improve the implementation of good governance in running his/her duties. All of government apparatus and agencies should always improve the effectiveness of internal control and internal audit function and also improve the organization commitment, 
because those factors improve the good governance.

Future researchers can add other variables that have a link with good governance, such as corporate culture, management style, and enterprise risk management, etc..

\section{References}

Allen, N. J., \& Meyer, J. P. (2000). Affective, continuance, and normative commitment to the organization: An examination of construct validity. Journal of Vocational Behavior, 49, 252-276.

Angle, H. L., \& Perry, J. L. (1981). An empirical assessment of organization commitment and organizational effectiveness. Administrative Science Quarterly, 26, 1-13.

Arens, A. A., Elder, R. J., \& Beasley, M. S. (2010). Auditing and assurance services: An integrated approach (13th ed.). New Jersey: Prentice Hall Inc..

Asian Development Bank. (1999). Governance: Sound development management. Retrieved from http://www.ggg.co.id/index.pdf

Brown, B. B. (2003). Employees' organizational commitment and their perception of supervisors' relations-oriented and task-oriented leadership behaviors (Dissertation at Faculty of the Virginia Polytechnic Institute and State University, Virginia, USA). Retrieved from http://www.google.com/pdf

Carcello, J., Hermanson, D., \& Raghunandan, K. (2005). Changes in internal auditing during the time of the major US accounting scandals. International Journal of Auditing, 9, 117-127.

Carey, P., Tanewski, G., \& Simnett, R. (2000). Voluntary demand for internal and external auditing by family businesses. Auditing: A Journal of Practice and Theory, 19, 37-51.

Cheung, T. C., \& Qiang, C. (2002). Internal audit at Guangdong nuclear power joint venture Company limited. Managerial Auditing Journal, 12(4), 219-232.

Committee of Sponsoring Organization of The Treadway Commission (COSO). (1999). Internal control integrated framework. New York: AICPA Publication.

Coram, P., \& Moroney, R. (2007). The importance of internal audit in fraud detection (Monash University Working Paper). Retrived from http://www.google.com

Ghazali, I. (2006). The aplication of multivariate analysis with SPSS. Semarang, Indonesia: Diponegoro University Publishing.

Gramling, A. A., Maletta, M. J., Schneider, A., \& Church, B. K. (2004). The role of the internal audit function in corporate governance: A synthesis of the extant internal auditing literature and directions for future research. Journal of Accounting Literature, 23, 194-244.

Gujarati, D. N. (2003). Basic econometric (4th ed.). Boston: Mc. Graw Hill.

John, P. M., David, J. S., Lynne, H., \& Laryssa, T. (2002). Affective, continuance, and normative commitment to the organization: A meta-analysis of antecedents, correlates, and consequences. Journal of Vocational Behavior, 61, 20-52.

Kajola., \& Sunday, O. (2008). Corporate governance and firm performance: The case of nigerian listed firms. European Journal of Economics, Finance and Administrative Sciences, 14, 16-28.

Mardiasmo, P. (2004). Indonesian public sector accounting. Jogjakarta, Indonesia: Andi Publishing.

Mensah, S., Aboagye, K., Addo, E., \& Buatsi, S. (2003). Corporate governance and corruption in Ghana: Empirical finding and policy. African Capital Market Forum, Accra, Ghana. Retrieved from http://www.google.com/pdf

Meyer, J. P., \& Allen, N. J. (1997). Commitment in the workplace: Theory, research, and application. Thousand Oaks, C.A.: Sage.

Moeller, R. R. (2005). Brink's Modern Internal Auditing (6th ed.). New Jersey: John Wiley \& Son.

Mowday, R. T., Stees, R. M., \& Porter, L. W. (1979). The measurement of organization commitment. Journal of Vocational Behavior, 4, 224-247.

National Committee on Governance Policy. (2010). General guide for good public governance. Jakarta, Indonesia: National Committe on Governance Policy Publishing.

Nila, P., \& Viriyanti. (2008). The relatinship between internal control and good corporate governance (survey on state owned enterprises in Bandung, Indonesia) (Widyatama University working paper). Retrived from http://www.di.tamu.edu and http://www.dspace.org

Porter, L. W., Steers, R. M., Mowday, R. T., \& Boulian, P. V. (1974). Organization commitment, job satisfaction, and turnover among psychiatric technicians. Journal of Applied Psychology, 59, 603-609.

Pratolo, S. (2007).Good corporate governance and the performance of state owned enterprises in Indonesia. National Symposium of Accounting $X$. Makasar, Indonesia. 
Professional Accountant in Business Committee (PABC). (2006). Internal control: A review of current development. International Federation of Accountant, New York. Retrieved from http://www.google.com/pdf

Punyaratabandhu, S. (2004). Commitment to good governance, development, and poverty reduction: Methodological issues in the evaluation of progress at national and local levels. Committee on Development Policy, Thailand. Retrieved from http://www.google.com/pdf

Ratliff, L. R., Wallace, A. W., Loebbecke, K. J., \& Farlan, M. G. (1996). Internal auditing principle and techniques. Florida: The Institute of Internal Auditor.

Sawyer, B. L., Mortimer, A. D., James, H., \& Schneider, H. (2003). Sawyer's internal auditing. Florida: The Institute Internal Auditing (IIA).

Stanton, G., Weiss, M., \& Emerson, J. (2003). Mainstreaming capital access for nonprofit. Retrived from www.ncced.org

Steers, R. M. (1977). Antecedents and outcomes of organizational commitment. Administrative Science Quarterly, 22, 46-56.

Stewart, J. G., \& Kent, P. (2006). The relation between external audit fees, audit committee characteristics and internal audit. Bond University electronic publication. Retrived from http://epublication.bond.edu.au/business_pubs/14

Schneider, H. (1999). Participatory governance: The missing link for poverty reduction, policy brief No. 17. Paris: OECD Development Centre.

Transparency International (TI). (2009). Corruption index. Retrieved from http://www.ti.or.id

Virginia, A., Eleni, K., Dimitrios, P., \& Chrysoula, X. (2009). The role of financial accounting information in strengthening corporate control mechanisms to alleviate corporate corruption (University Macedonia Working Paper). Retrieved from http://www.google.com/pdf

Wallace, W., \& Kreutzfeldt, R. (1991). Distinctive characteristics of entities with an internal audit department and the association of the quality of such departments with errors. Contemporary Accounting Research, 7(2), 485-512.

World Bank. (2003). Public sector governance: Indicators of governance and institutional quality. Washington, D. C.: World Bank.

Yasin, N., Ghaneem, M. J., \& Rustom, L. (2011).The role of internal audit function in corporate governance: An empirical study on commercial banks in Lebanon (Working Paper of Beirut Arab University). Retrieved from http://www.google.com.pdf 